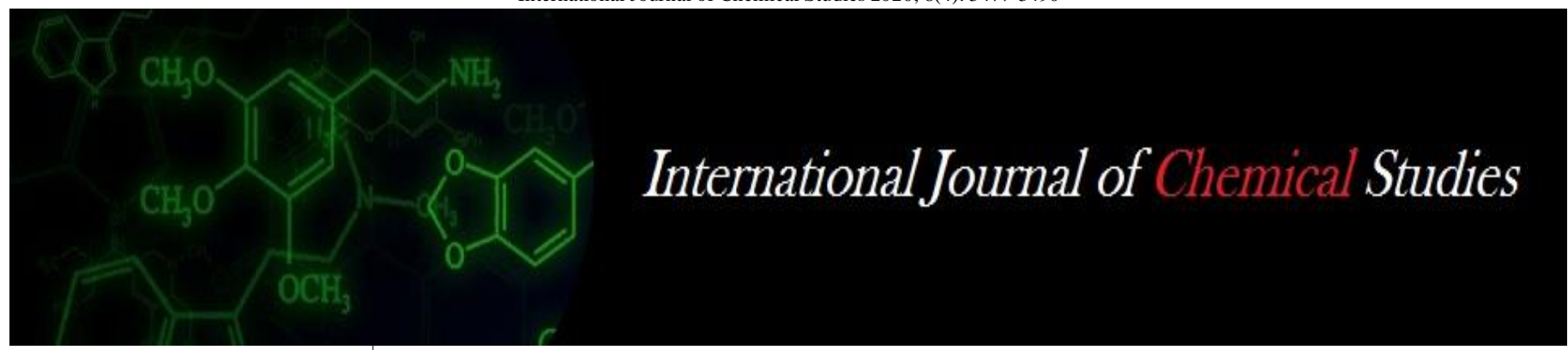

P-ISSN: 2349-8528

E-ISSN: 2321-4902

www.chemijournal.com

IJCS 2020; 8(4): 3477-3490

(C) 2020 IJCS

Received: 04-05-2020

Accepted: 06-06-2020

R Parimala devi

National Pulses Research Centre, Tamil Nadu Agricultural

University, Coimbatore, Tamil

Nadu, India

P Marimuthu

Department of Agricultural

Microbiology, Tamil Nadu

Agricultural University,

Coimbatore, Tamil Nadu, India

\section{Identification of antimicrobial compounds in chloroform extract of Polygonum minus}

\author{
R Parimala devi and P Marimuthu
}

DOI: https://doi.org/10.22271/chemi.2020.v8.i4ar.10190

\begin{abstract}
Medicinal plants remains as a major source of antimicrobial compounds against plant and human pathogens. The antimicrobial activity of the chloroform extract of Polygonum minus was well documented in our earlier studies. The current study was performed with the aim to detect the chemical compounds peresent in the chloroform extract of Polygonum minus. Thin layer chromatography (TLC) was performed for partial purification and separation of antimicrobial compounds from the plant extract. The bands obtained from TLC were collected and assayed for their antimicrobial activity against the selected plant pathogens of study. Active bands identified by TLC were further purified by using high performance liquid chromatography (HPLC). The fractions showing maximum peak area and yield were taken for further analysis in GC-MS to identify the antimicrobial compounds. GC-MS analysis revealed that the compounds like 1,2-heptadiene, ditetrazolo $\left(1,5-\mathrm{a}: 5^{\prime}, 1^{\prime}-\mathrm{c}\right)$ pyrazine, allylcyclopropane and 6ethyl-2,3,11,12-dibenzo-1,4,7,10,13, 16-hexaoxacyclooctadeca-2,11-diene may be present in the chloroform extract of $P$. minus.
\end{abstract}

Keywords: Polygonum minus, antimicrobial compounds, chromatography

\section{Introduction}

"There is no substance in the universe which cannot be used as a drug for a rational objective" - Charak samhita: su: 26: R

Plants of our planet provide shelter, cloth, food, medicines, etc to the humankind. India is gifted with rich plant resources and a major portion is used in our traditional health care systems. In the field of agriculture, the major economic loss occurs due to the incidence of pests and diseases. Use of synthetic chemicals controls the crop pests in an effective manner and at the same time excessive usage leads to occurrence of resistance and resurgence in pests and residual effect in the environment and agricultural products. As an alternate to the synthetics, botanicals can be exploited for crop protection to avoid the ill effects. Use of botanicals in plant disease management assumes special significance by being an ecofriendly and cost effective strategy, which can be used in integration with other strategies for a greater levels of protection with sustained crop yields. This era of production and productivity did improve availability of food grains but affected the agro ecosystem adversely. Crude extracts of some well known medicinal plants are used to control some of the plant pathogens. The identification of active chemical compounds present in the crude extract may lead to develop new plant based biopesticides for crop protection measures to answer the problems of residual effect on the environment and agricultural products. With this in view, the present study is formulated with the aim to identify the active chemical compounds present in the chloroform extract of Polygonum minus.

\section{Materials and methods}

Separation of antimicrobial compounds through thin layer chromatography (TLC)

Thin layer chromatographic studies were carried out to separate the antimicrobial compound present in the chloroform extract of the P. minus (Sadasivam and Manickam, 2005) ${ }^{[29]}$.

\section{Separation of antimicrobial compounds through TLC}

Different solvent systems (ranging from low polar to high polar) were tested for the effective separation of antimicrobial compounds from chloroform extract of $P$. minus. A suitable mobile
R Parimala devi

National Pulses Research Centre, Tamil Nadu Agricultural

University, Coimbatore, Tamil

Nadu, India 
phase was standardized based on the separation of antimicrobial compounds. The TLC run plates were observed under bright light and the separated spots were marked. The Relative front values were calculated by using the given formula

\section{Distance moved by the solute from the origin \\ Rf value $=$ Distance moved by the solvent from the origin}

\section{Detection of chemical groups}

In pre-coated silica gel sheets, chloroform extract of plant $P$. minus was run using the suitable mobile phase and after TLC separation the sheets were kept in room temperature for drying. The TLC sheets were sprayed with chemical reagents $v i z$, folins reagent, vanillin sulphuric acid, phosphomolybdic acid, dragendroffs reagent, diazotized sulphanillic acid and the observations were made.

\section{Determination of minimum inhibitory concentration (MIC)}

The MIC was performed to test the antimicrobial activity of the chloroform extract of $P$. minus and active bands using tube dilution method (Claeys et al., 1988) ${ }^{[7]}$. The MIC (minimum inhibitory concentration) was defined as the lowest concentration of antibiotics or plant extracts that did not show any growth of tested pathogens at a minimum concentration. This test was performed at four concentrations of the plant extract $(10 \mathrm{mg} / \mathrm{ml}, 1 \mathrm{mg} / \mathrm{ml}, 0.1 \mathrm{mg} / \mathrm{ml}$ and $0.01 \mathrm{mg} / \mathrm{ml})$. Active culture of each organism was used for the study. $10^{-4}$ dilution of each organism was prepared by serial dilution technique. The plates were then covered and incubated for 24 hours. The growth of the organism for each dilution was observed and thus the Minimum Inhibitory Concentration of the plant extract was calculated.

\section{Inhibitory concentration 50 (IC50) (Phongpaichit et al., 2004) ${ }^{[27]}$}

The inhibitory concentration 50 (IC50) was performed to test the antifungal activity of the active bands using tube dilution method. IC50 is defined as a concentration at which 50 per cent mortality of organisms is observed. Active cultures of each organism were used in the study.

The per cent inhibition of organism by test sample is calculated by the given formula

Percentage of inhibition by compounds $=\frac{(\text { Control }- \text { sample })}{\text { Control }} \times 100$

\section{Purification of antimicrobial compounds through RP- HPLC}

Analysis of the active bands was done in HPLC - Hitachi model L 6200 equipped with LC8A pump, SPD-M 10A $\gamma p$ photo diode array (PDA) detector in combination with class LC 10A software and Beckman Ultrasphere supelco ODS column $(250 \times 4.6 \mathrm{~mm})$ was used.

\section{Identification of compounds using GC-MS}

GC-MS analysis was carried out by using Perkin Elmer Clarus 500 GC-MS unit. The analysis was carried out to detect the possible compounds present in the active fractions of the plant extract.

\section{Chemicals}

All the chemicals used were of Analytical Reagent (AR) grade obtained from Hi-media, Qualigens, E-Merck and SigmaAldrich.

\section{Results}

Thin layer chromatography (TLC) studies

Different solvent systems (ranging from low polar to high polar) were tested for effective separation of the antimicrobial compounds from chloroform extract of $P$. minus. Hundred per cent dichloromethane was standardized as the suitable mobile phase, since best separation of the antimicrobial compounds has been achieved with this mobile phase.

A total of 11 bands were observed, of which 7 bands were visible (Plate 1) and 4 bands were invisible (Table 1) and thus identified by using spray reagents (Folin-Ciocalteau reagent and 20 per cent sodium carbonate solution, vanillin sulphuric acid, diazotized sulphanillic acid, dragendroffs reagent and phosphomolybdic acid). The four invisible bands appeared as pink and purple colour, upon spraying with vanillin sulphuric acid indicating the presence of terpenoid group of compounds in the extract (Plate 2).

\section{Agar well diffusion assay of bands obtained from chloroform extract of $P$. minus Plant pathogens}

All the eleven bands which were obtained from TLC of chloroform extract of $P$. minus were tested for their antimicrobial activities against the test organisms. The band 7 with an Rf value of $0.43 \mathrm{~cm}$ was found to be effective against $A$. helianthi, A. solani, A. flavus, A. niger and $F$. oxysporum f.sp. lycopersici with inhibition zones of 1.8, 3.7, 3.3, 3.4 and $3.8 \mathrm{~cm}$ respectively (Table 2 ). In all the other bands little or no inhibition was observed against all the tested fungi. The inhibition zone produced by the band 7 against $A$. helianthi $(1.8 \mathrm{~cm})$ was not comparable to that of the standard antifungal agent ketoconazole $(3.9 \mathrm{~cm})$. Hence detailed study on $A$. helianthi was not taken up.

Minimum inhibitory concentration for band 7 of chloroform extract of $P$. minus by tube dilution method against plant pathogens

The minimum inhibitory concentration of band 7 of chloroform extract of $P$. minus was assayed against $A$. solani, A. flavus, A. niger and $F$. oxysporum f.sp. lycopersici by means of tube dilution method (Table 3). The band 7 showed the inhibitory effect at $10 \mathrm{mg}$ and $1 \mathrm{mg} / \mathrm{ml}$ concentrations. Ketoconazole (positive control) inhibited the growth of all these organisms at dilution $1(10 \mathrm{mg} / \mathrm{ml})$ and dilution $2(1$ $\mathrm{mg} / \mathrm{ml}$ ). Whereas, in the cells and ethanol (negative control) showed growth in all the four dilutions $(10 \mathrm{mg}, 1 \mathrm{mg}, 0.1 \mathrm{mg}$ and $0.01 \mathrm{mg} / \mathrm{ml}$ ).

Minimum inhibitory concentration for band 7 of chloroform extract of $P$. minus using ELISA reader against plant pathogens

MIC was assayed for band 7 of chloroform extract of $P$. minus by using microtitre plates of ELISA reader. The assay was performed at four concentrations viz., $10 \mathrm{mg}$, $1 \mathrm{mg}, 0.1 \mathrm{mg}$ and $0.01 \mathrm{mg} / \mathrm{ml}$ against A. solani, A. flavus, A. niger and $F$. oxysporum f.sp. lycopersici.

\section{A. solani}

The band 7 of chloroform extract of $P$. minus possessed antifungal activity against $A$. solani at concentrations of 10 $\mathrm{mg}$ and $1 \mathrm{mg} / \mathrm{ml}$ at various time intervals $\left(0^{\text {th }} \mathrm{hr}, 1^{\text {st }} \mathrm{hr}, 6^{\text {th }} \mathrm{hr}\right.$ and $24^{\text {th }} \mathrm{hr}$ ) (Table $\left.4 \mathrm{a}\right)$. Graphical representation of the results revealed that the minimum concentration of band 7 of chloroform extract of $P$. minus required to inhibit the growth of $A$. solani was $1 \mathrm{mg} / \mathrm{ml}$. 


\section{F. oxysporum f.sp. lycopersici}

Band 7 of chloroform extract of $P$. minus showed activity against $F$. oxysporum f.sp. lycopersici at concentrations of 10 $\mathrm{mg}$ and $1 \mathrm{mg} / \mathrm{ml}$ (Table 4b). In $0.1 \mathrm{mg}$ and $0.01 \mathrm{mg} / \mathrm{ml}$ concentrations, growth was observed in $F$. oxysporum f.sp. lycopersici at different hours viz., $0^{\text {th }} \mathrm{hr}, 1^{\text {st }} \mathrm{hr}, 6^{\text {th }} \mathrm{hr}$ and $24^{\text {th }}$ hr after inoculation. The MIC of the band 7 of chloroform extract of $P$. minus for $F$. oxysporum f.sp. lycopersici was found to be $1 \mathrm{mg} / \mathrm{ml}$.

\section{A. flavus}

The growth of $A$. flavus was found to be inhibited by band 7 of chloroform extract of $P$. minus at $10 \mathrm{mg}$ and $1 \mathrm{mg} / \mathrm{ml}$ concentrations uniformly at various time intervals (Table 4c). The growth of $A$. flavus was found to be sufficiently inhibited by band 7 of chloroform extract of $P$. minus at a concentration of $1 \mathrm{mg} / \mathrm{ml}$ and hence, this concentration was observed as the MIC for A. flavus.

\section{A. niger}

Band 7 of chloroform extract of $P$. minus inhibited the growth of $A$. niger at concentrations of $10 \mathrm{mg}$ and $1 \mathrm{mg} / \mathrm{ml}$ at $0^{\text {th }} \mathrm{hr}$, $1^{\text {st }} \mathrm{hr}, 6^{\text {th }} \mathrm{hr}$ and $24^{\text {th }} \mathrm{hr}$ (Table $4 \mathrm{~d}$ ). Whereas in $0.1 \mathrm{mg}$ and $0.01 \mathrm{mg}$ concentrations growth were observed. The MIC for A. niger was found to be $1 \mathrm{mg} / \mathrm{ml}$.

Minimum inhibitory concentration of band 7 of $P$. minus against plant pathogens at $1 \mathrm{mg}$ concentration in ELISA reader

Band 7 exhibited MIC of $1 \mathrm{mg} / \mathrm{ml}$ against all the plant pathogens. OD values obtained from ELISA reader, showed that the extract had a significant control on the growth of all the organisms during different time intervals (Table 5). Ketoconazole at $1 \mathrm{mg} / \mathrm{ml}$ concentration recorded significant control over the growth of the organisms. Increase in OD value was observed in ethanol and cells which indicated the growth of the organism.

Minimum inhibitory concentration for band 8 of chloroform extract of $P$. minus by tube dilution method against human pathogens

The minimum inhibitory concentration of band 8 of chloroform extract of $P$. minus obtained from thin layer chromatography was assessed against the selected human pathogens by tube dilution method (Table 6). The band 8 inhibited the growth of $S$. aureus, E. coli, P. aeruginosa, $C$. albicans and $C$. neoformans at $10 \mathrm{mg}$ and $1 \mathrm{mg} / \mathrm{ml}$ concentrations. Whereas growth was observed in the other two concentrations $(0.1 \mathrm{mg}$ and $0.01 \mathrm{mg} / \mathrm{ml})$ in all the test organisms. Ethanol (negative control) did not inhibit the growth of all organisms in all the four concentrations. The standard antibiotic chloramphenicol inhibited the growth of organisms at $10 \mathrm{mg}$ and $1 \mathrm{mg} / \mathrm{ml}$ concentrations invariably.

\section{Inhibitory concentration (IC50) for band 7 of chloroform} extract of $P$. minus against plant pathogens

Inhibitory concentration (IC50) was determined for band 7 of chloroform extract of $P$. minus against A. solani, A. flavus, A. niger and $F$. oxysporum f.sp. lycopersici. Fifty per cent inhibition of the organisms by the band 7 of chloroform extract of $P$. minus had been determined by microdilution method at various concentrations of the band viz., $1.0 \mathrm{mg}$. $0.75 \mathrm{mg}, 0.50 \mathrm{mg}$ and $0.25 \mathrm{mg} / \mathrm{ml}$ (Table 7). Hundred per cent ethanol was used to dissolve the band and hence 100 per cent ethanol was used as the negative control. Likewise ketoconazole was used as the positive control.

The concentration at which 50 per cent of the colonies have been inhibited when compared to the control was determined as inhibitory concentration (IC50). Fifty per cent inhibition of the colonies of organisms- A. flavus (49) and A. niger (53) was observed in $0.75 \mathrm{mg} / \mathrm{ml}$ concentration and for $A$. solani (38) and $F$. oxysporum f.sp. lycopersici (33) 50 per cent inhibition was observed in $0.5 \mathrm{mg} / \mathrm{ml}$ concentration when compared to the control (A. flavus (97), A. niger (106), A. solani (79) and F. oxysporum f.sp. lycopersici (67).

\section{Purification of antimicrobial compounds of chloroform extract of $P$. minus through high performance liquid chromatography (HPLC)}

HPLC studies were performed to purify the antimicrobial compounds present in the band 7 and band 8 of chloroform extract of $P$. minus. Band 7 and 8 obtained from thin layer chromatography of chloroform extract of $P$. minus was subjected to HPLC. The bands were dissolved in HPLC grade methanol at a concentration of $10 \mathrm{mg} / \mathrm{ml}$. Analytical HPLC was run with the mobile phase of acetonitrile: water (75:25). The flow rate was maintained at $1 \mathrm{ml} / \mathrm{min}$ and the run time was for 30 minutes and the detection wavelength was $245 \mathrm{~nm}$. The peak obtained during $1.7 \mathrm{~min}$ was suspected as the solvent peak and so that peak was not considered. For band 7 a total of 8 peaks excluding the solvent peak were obtained (peak 1- $2.3 \mathrm{~min}$, peak 2 - $2.5 \mathrm{~min}$, peak 3 - $3.0 \mathrm{~min}$, peak $4-$ 3.5 min, peak $5-3.9$ min, peak $6-4.2 \mathrm{~min}$, peak $7-5.4 \mathrm{~min}$ and peak 8-5.9 min) (Fig. 1) and for band 8 a total of 9 peaks excluding the solvent peak were obtained (peak 1- $5.2 \mathrm{~min}$, peak $2-5.9 \mathrm{~min}$, peak $3-7.5 \mathrm{~min}$, peak $4-9.5 \mathrm{~min}$, peak $5-$ 10.4 min, peak $6-11.2$ min, peak $7-12.0$ min, peak $8-13.6$ min and peak $9-15.5 \mathrm{~min}$ ) (Fig. 2). The fraction 2 (2.5 min and fraction 8 (5.9 $\mathrm{min})$ of band 7 showing maximum peak area and yield were taken for further analysis in GC-MS. The fraction $2(5.9 \mathrm{~min})$ and fraction $9(15.5 \mathrm{~min})$ of band 8 showing maximum peak area and yield were taken for further analysis in GC-MS to identify the antimicrobial compounds.

\section{GC-MS analysis}

GC-MS analysis was conducted to identify the active antimicrobial compounds present in the chloroform extract of P. minus.

\section{GC-MS analysis of HPLC fraction 2 of band 7}

Single peak was obtained for HPLC fraction 2 of band 7 in GC-MS. The compound present in HPLC fraction 2 of band 7 have the base peak of 53.9, retention time of $2.169 \mathrm{~min}$ and molecular weight -96 . The given library match for this compound may be 1,2-heptadiene (Fig. 3).

\section{GC-MS analysis of HPLC fraction 8 of band 7}

Single peak with retention time of 2.285 min was obtained for HPLC fraction 8 of band 7 in GC-MS. The compound present in HPLC fraction 8 of band 7 have the base peak of 54.0, retention time of $2.285 \mathrm{~min}$ and molecular weight -162 . The given library match for this compound may be ditetrazolo (1,5-a:5',1'-c) pyrazine (Fig. 4).

\section{GC-MS analysis of HPLC fraction 2 of band 8}

Single peak was obtained for HPLC fraction 2 of band 8 in GC-MS. The compound present in HPLC fraction 2 of band 8 have the base peak of 53.9, retention time of $2.133 \mathrm{~min}$ and 
molecular weight -82 . The given library match for this compound may be allylcyclopropane (Fig. 5).

\section{GC-MS analysis of HPLC fraction 9 of band 8}

Two peaks with retention time of 2.179 and 2.320 respectively were obtained for HPLC fraction 9 of band 8 in GC-MS. The compound present in HPLC fraction 9 of band 8 have the base peak of 54, retention time of $2.179 \mathrm{~min}$ and molecular weight -388 . The given library match for this compound may be 6-ethyl-2,3,11,12-dibenzo-1,4,7,10,13,16hexaoxacyclooctadeca-2,11-diene (Fig. 6). According to the GC-MS library match these were the related compounds that may be present in chloroform extract of $P$. minus.

\section{Discussion \\ Thin layer chromatographic (TLC) studies of plant extract}

Qualitative analysis of biochemical compounds present in plant extracts is mandatory for identifying a particular compound or a group of compounds responsible for furnishing antimicrobial action. To accomplish this, TLC studies were employed.

A combination of column chromatography (CC) and preparative thin layer chromatography (PTLC) of the ethyl acetate extract of whole plants of Polygonum viscosum yielded the known flavone, 3',5-dihydroxy-3,4',5',7-tetra methoxyflavone

(Datta et al., 2000) ${ }^{[8]}$. Apers et al. (2004) ${ }^{[1]}$ examined twentyone collections belonging to Phyllanthus niruri for the distribution of flavonoids using TLC. Aqueous methanolic extracts were applied on TLC silica gel plates and the dimensional chromatography was carried in n-butanol : acetic acid : water (4:1:5) as mobile phase. The flavonoids composition was analyzed with UV max.

In the present study, the chloroform extract of $P$. minus was subjected to TLC separation, using 100 per cent dichloromethane as mobile phase. A total of 11 bands were obtained. Six bands were found to be visible and the other four bands were observed using spray reagents. Spraying of vanillin sulphuric acid revealed the presence of terpenoids in the extract. This result is in accordance with Duwiejuva et al. (1999) [9] who reported the presence of terpenoids in Polygonum sp.

All the 11 bands were collected separately and tested for their antimicrobial activity against the selected plant and human pathogens.

\section{Minimum inhibitory concentration method for evaluation of antimicrobial activity}

The MIC (minimum inhibitory concentration) was defined as the lowest concentration of antibiotics or plant extracts that did not show any growth of tested pathogens at a minimum concentration. The minimum inhibitory concentration of medicinal plants was reported by several workers (Manmoud et al., 1999; Bonjar et al., 2003; Voravuthikunchai et al., 2004; Abere et al., 2007) ${ }^{[21,6,39,2]}$.

Claeys et al. (1988) ${ }^{[7]}$ reported that, the minimum inhibitory concentration of Lantana camara leaf extract up to $20 \mu \mathrm{g}$ per $\mathrm{ml}$ against various plant pathogens including Aspergillus niger and Aspergillus fumigatus. Iqbal et al. (1998) ${ }^{[14]}$ found that aqueous extract of Terminalia chebula and Terminalia bellerica manifested a better MIC against $E$. coli $(0.6 \mu \mathrm{g}$ per $\mathrm{ml})$. The lowest MIC was observed in the aqueous extract of Myrtus communis and Terminalia chebula as $0.31 \mathrm{mg}$ against Candida albicans and Candida utilis (Bonjar, 2004) ${ }^{[5]}$. Rao et al. (2006) [28] reported that the minimum inhibitory concentration of Achyranthes aspera against Fusarium udum and Aspergillus niger are $30 \mu \mathrm{g}$ and $40 \mu \mathrm{g}$ respectively. The methanolic extracts of $P$. cupsidatum roots possessed the MIC of $156.3-312.5 \mu \mathrm{g} / \mathrm{ml}$ against Bacillus cereus, Listeria monocytogenes and Staphylococcus aureus (Shan et al., 2008) [30]

In the present study, the minimum inhibitory concentration of chloroform leaf extract of $P$. minus was found to be $10 \mathrm{mg} / \mathrm{ml}$ for all the plant pathogens tested.

\section{Minimum inhibitory concentration by ELISA reader}

A serial two-fold macro broth dilution was performed to determine the MIC of CTC and SMZ for Mycobacterium hemolyticum and $H$. somnus. Stationary phase cultures of all strains were prepared at both $37^{\circ} \mathrm{C}$ and $47^{\circ} \mathrm{C}$ and used to inoculate fresh $5 \mathrm{ml}$ cultures to an $\mathrm{OD}_{620}$ of 0.05 . The $5 \mathrm{ml}$ cultures were then incubated at either $37^{\circ} \mathrm{C}$ or $41^{\circ} \mathrm{C}$ until an $\mathrm{OD}_{620}$ of 0.01 was achieved from which standardized bacterial suspensions were prepared to a final cell density of $5 \times 10^{5}$ $\mathrm{cfu} / \mathrm{ml}$ (Adelina et al., 2002) ${ }^{[3]}$

In the present study, MIC assay was carried out by using ELISA reader for band 7 of $P$. minus against $A$. solani, $A$. flavus, $A$. niger and $F$. oxysporum f.sp. lycopersici at concentrations of $10 \mathrm{mg}, 1.0 \mathrm{mg}, 0.10 \mathrm{mg}$ and $0.01 \mathrm{mg} / \mathrm{ml}$. The minimum inhibitory concentration of bands was found to be $1.0 \mathrm{mg} / \mathrm{ml}$ by using ELISA reader.

The minimum inhibitory concentration for the bands was lower than the extract, this might be due to the reason that the purity of antimicrobial compounds may be higher in bands collected from thin layer chromatography than the crude extract of $P$. minus.

\section{Inhibitory concentration (IC50)}

Inhibitory concentration (IC50) is defined as a concentration at which 50 per cent mortality of organisms is observed. The plant extracts of Alangium sanviifolium, Tachyspermum ammi, Terminalia bellerica, Acacia catechu and Plumbago indica were active against Aspergillus niger and Candida albicans at a concentration of $50 \mathrm{mg} / \mathrm{ml}$. Only 11 per cent of the extracts were active against Aspergillus niger and 8 per cent against Candida albicans at a concentration of $50 \mathrm{mg} / \mathrm{ml}$ (Wagavi et al., 1999) ${ }^{[40]}$.

In the present study, inhibitory concentration (IC 50) assay was carried out by tube dilution method for band 7 of $P$. minus against $A$. solani, A. flavus, A. niger and $F$. oxysporum f.sp. lycopersici at concentrations of $1.0 \mathrm{mg}, 0.75 \mathrm{mg}, 0.50$ $\mathrm{mg}$ and $0.25 \mathrm{mg} / \mathrm{ml}$. Fifty per cent inhibition of the colonies of organisms- A. flavus (49) and A. niger (53) was observed in $0.75 \mathrm{mg} / \mathrm{ml}$ concentration and for A. solani (38) and F. oxysporum f.sp lycopersici (33) 50 per cent inhibition was observed in $0.5 \mathrm{mg} / \mathrm{ml}$ concentration when compared to the control (A. flavus (97), A. niger (106), A. solani (79) and $F$. oxysporum f.sp. lycopersici (67).

The inhibitory concentration 50 (IC50) was not similar for all the microbes tested. This difference may be due to the occurrence of physiological and morphological variations among the microorganisms tested.

\section{High performance liquid chromatography}

Hahn et al. (1993) ${ }^{[12]}$ separated and quantified ten substituted benzoic and cinnamic acid (phenolic acids) of pea by using reversed phased high performance liquid chromatography. Direct preparative high performance liquid chromatography of the active fractions from the 90 per cent methanol extract 
of Azadirachta indica and subsequent bioassay of the semi pure fractions indicated that the active fractions contain major compounds such as 6 deacetylnimbin, azadiradione, nimbin, salannin and epoxyazadiradione (Govindachari et al., 1998) [11].

Reverse phase - high performance liquid chromatography analysis of methanol extract of $P$. viscosum provided two novel metabolites, quercetin 3-O- (6"-ferulolyl)- $\beta-\mathrm{D}$ galactopyranoside and 4-isobutyl-6-methyl-5-oxo-3a,4,5,7atetrahydro-1 $H$-inden-13-oic acid (named viscosumic acid) (Datta et al., 2000) ${ }^{[8]}$. A new, simple and rapid high performance liquid chromatography (HPLC) method compatible with MS detection was developed and validated by Fernand et al. (2005) ${ }^{[10]}$ to qunantify oleanolic and ursolic acids in Mitracarpus scaber. The mobile phase acetonitrile: water (85:15) was pumped through a $\mathrm{C}_{18}$ ODS (Octa Decyl Silyl) column at a flow rate of $0.6 \mathrm{ml} / \mathrm{min}$ and the eluate was monitored at $250 \mathrm{~nm}$. The detection limit (taken as a peak height 3 times the noise level) was determined as $0.2 \mu \mathrm{g} / \mathrm{ml}$ and the quantification limit was calculated as $0.5 \mu \mathrm{g} / \mathrm{ml}$ for the two acids.

In the present study, using Shimadzu HPLC the chloroform extract of $P$. minus was analyzed. The mobile phase acetonitrile: water $(75: 25)$ was pumped through a $\mathrm{C}_{18}$ ODS (Octa Decyl Silyl) column at a flow rate of $1.0 \mathrm{ml} / \mathrm{min}$ and the eluate was monitored by UV detector at $245 \mathrm{~nm}$ for 30 minutes. For band 7 a total of 8 peaks excluding the solvent peak and for band 8 a total of 9 peaks excluding the solvent peak were obtained. Occurrence of more than one peak indicated the presence of more than one molecule in both the fractions. The HPLC fraction 2 and fraction 8 of band 7 and fraction 2 and fraction 9 of band 8 were collected for further analysis by GC-MS.

\section{GCMS studies}

Gas chromatography mass spectrometry identify the compounds based on their retention indices (determined with reference to a homologous series of normal alkanes), and by comparison of their mass spectral fragmentation patterns.

Polygonum sp. is well known for producing a variety of secondary metabolites including flavanoids (Sartor et al., 1999; Peng et al., 2003) ${ }^{[31,26]}$, triterpenoids (Duwiejua et al., 1999) [9], anthraquinones (Matsuda et al., 2001; Yim et al., 1998) [22, 42], coumarins (Sun and Sneden, 1999) [32], phenylpropanoids (Murai et al., 2001; Takasaki et al., 2001) [23, 33], lignans (Kim et al., 1994) ${ }^{[17]}$, sesquiterpenoids (Datta et al., 2000) ${ }^{[8]}$, stilbenoids (Nonaka et al., 1982) ${ }^{[24]}$ and tannins (Wang et al., 2005) ${ }^{[41]}$.

The active compounds of $P$. cupsidatum have been identified as 2. methoxy-6-acetyl-7-methyljuglone (Kimura et al., 1983) ${ }^{[18]}$, emodin (Jayasuriya et al., 1992) ${ }^{[15]}$, polygonin, emodin mono ethyl ether and chrysophano (Park and Lee, 2000) ${ }^{[25]}$. Glycosides, reynoutin, avicularin and hyperin were found in its leaves (Huang, 1993) ${ }^{[13]}$ and mainly stilbenes (Vastano et al., 2000) ${ }^{[38]}$ in its roots.

GC-MS analysis of volatile extracts of $P$. hydropiper by Jiang $(2005)^{[16]}$ revealed the presence of 46 compounds, including 14 carbonyls, 14 alchohols, 10 hydrocarbons, four esters, four furans one acid and one base. A total of 24 compounds were identified by GC-MS analysis of the volatile oil of $P$. orientale. Terpenes constituted 27.36 per cent of the total compounds (Ling and Ai-Yang, 2008) ${ }^{[20]}$.

In our present investigation, gas chromatography mass spectrometry studies were carried out for four major fractions ( 2 fractions of band 7 and 2 fractions of band 8 ) obtained from the HPLC. The GC-MS analysis resulted in single peak for both the fractions of band 7 and fraction 2 of band 8 whereas two peaks were obtained for fraction 9 of band 8 . The library match of the GC-MS showed that the compounds like 1,2-heptadiene, ditetrazolo (1,5-a:5',1'-c) pyrazine, allylcyclopropane and 16-ethyl-2,3,11,12-dibenzo 1,4,7,10, 13,16-hexaoxacyclooctadeca-2,11-diene may be present in the chloroform extract of $P$. minus.

\section{Antimicrobial activity of the identified compounds}

The results of the present study showed that the compounds ditetrazolo (1,5-a:5',1'-c) pyrazine, allylcyclopropane, 1,2heptadiene and 6-ethyl-2,3,11,12-dibenzo-1,4,7,10,13,16 hexaoxacyclooctadeca -2,11-diene may be present in the chloroform extract of $P$. minus.

Krivopalov et al. (1989) ${ }^{[19]}$ have reported that ditetrazolo $\left(1,5-\mathrm{a}: 5 ', 1^{\prime}-\mathrm{c}\right)$ pyrazine is a tautomer of ditetrazolo (1,5-a:5', $1^{\prime}-$ c) quinoxalines. The antimicrobial activity of ditetrazolo (1,5a:5', 1'-c) quinoxalines have been reported and patented by many workers. A class of ditetrazolo (1,5-a:5',1'-c) quinoxalines has been found to be useful for protecting plants from soil-borne phytopathgens, such as fusarium root rot, rhizoctonia damping-off and verticillium wilt (US patent, 3988455). The protection of plants from foliar and soil-borne phytopathogens is accomplished by the treatment of the plants with a specified class of ditetrazolo (1,5-a:5',1'-c) quinoxalines (US patent, 3987196). A new method of reducing the adverse effect of rice blast, an important disease of rice, is accomplished by spraying triazolo (4,3-a) quinoxalines to the foliage of the rice plants (US patent, 4008322). These findings supported the results of our present study, that the compound ditetrazolo $\left(1,5-\mathrm{a}: 5^{\prime}, 1^{\prime}-\mathrm{c}\right)$ pyrazine found in the fraction 7 , may be responsible for the antifungal activity possessed by the chloroform extract of $P$. minus.

The antimicrobial activity of the allyl group of compound has been well documented. Tsao and Yin (2001) ${ }^{[34]}$ reported the antimicrobial acitivity of four diallyl sulphides. The bactericidal effect of allyl isothiocyanate on Listeria monocytogenes has also been investigated (Ahn et al., 2001) [4]. These findings supported the results of our present findings, that the compound allylcyclopropane identified in the fraction 8 may be responsible for the antibacterial activity of the chloroform extract of $P$. minus.

The allyl group of compounds are common in onion and garlic. The volatile antimicrobial substance (diallyl compounds) is produced when the plant tissues are damaged. These substances are membrane permeable and undergo thiol sulphide exchange reaction with free thiol group in proteins. It is thought that these properties are the basis of its antimicrobial action. The quinoxaline group of compounds inhibits the synthesis of DNA and this may be the possible mechanism of action of the identified compounds in the present study.

It has been concluded that the medicinal plant $P$. minus possessed broad spectrum of antimicrobial activity against various plant pathogens. The minimum inhibitory concentration of the purified fractions by thin layer chromatography was found to be lesser $(1 \mathrm{mg} / \mathrm{ml})$ than that of the crude extract $(10 \mathrm{mg} / \mathrm{ml})$ and this might be due to the reason that, the compound responsible for the antimicrobial activity is available in high concentration and pure form in the fraction when compared to the crude extract. The fractions also exhibited good inhibitory concentration (IC50) levels against the selected pathogens. The TLC, HPLC and GC-MS analysis revealed that the compounds like 1,2-heptadiene, 
ditetrazolo (1,5-a:5',1'-c) pyrazine, allylcyclopropane and 6ethyl-2,3,11,

12-dibenzo-1,4,7,10,13,

16 hexaoxacyclooctadeca-2,11-diene may be present in the chloroform extract of $P$. minus. The antimicrobial activity of ditetrazolo (1,5-a:5',1'-c) pyrazine and allylcyclopropane has been well documented. Detailed studies like Nuclear Magnetic Resonance (NMR) on these identified compounds may yield more information about the exact nature of these active antimicrobial compounds identified in $P$. minus.

\section{a) Visible observation}

Table 1: Thin layer chromatography (TLC) of chloroform leaf extract of $P$. minus

\begin{tabular}{|c|c|c|c|}
\hline Band No. & Color of the band & Distance traveled (cm) & Rf value (cm) \\
\hline 1 & Light green & 0.75 & 0.08 \\
\hline 2 & Yellowish green & 1.20 & 0.13 \\
\hline 3 & Ivory & 1.50 & 0.16 \\
\hline 4 & Light yellow & 2.0 & 0.22 \\
\hline 5 & Green & 2.2 & 0.24 \\
\hline 6 & Ash & 2.4 & 0.26 \\
\hline 11 & Yellow & 9.2 & 1.0 \\
\hline
\end{tabular}

\section{b) Bands observed using spray reagents}

\begin{tabular}{|c|c|c|c|}
\hline \multirow{2}{*}{ Band No. } & \multicolumn{3}{|c|}{ Spray reagent - Vanillin sulphuric acid } \\
\cline { 2 - 4 } & Color of the band & Distance traveled (cm) & Rf value (cm) \\
\hline 7 & Pink & 4.0 & 0.43 \\
\hline 8 & Purple & 4.3 & 0.47 \\
\hline 9 & Pink & 5.7 & 0.62 \\
\hline 10 & Purple & 8.3 & 0.90 \\
\hline
\end{tabular}

Mobile phase: 100 per cent dichloromethane

Table 2: Antimicrobial activity of TLC separated bands of chloroform leaf extracts of $P$. minus against plant pathogens by agar well diffusion assay

\begin{tabular}{|c|c|c|c|c|c|c|}
\hline \multirow{2}{*}{ Band No. } & \multicolumn{6}{|c|}{ Diameter of inhibition zone in cm } \\
\cline { 2 - 6 } & A. helianthi & A. solani & A. flavus & A. niger & F. oxysporum f.sp. lycopersici \\
\hline \multicolumn{7}{|c|}{ Visible observation } \\
\hline 1 & - & - & - & - & - \\
\hline 2 & - & - & - & - & - \\
\hline 3 & 0.6 & 1.1 & 0.9 & 0.8 & 0.7 \\
\hline 4 & 0.4 & 0.9 & 1.0 & 1.1 & 0.8 \\
\hline 5 & 0.5 & 0.5 & 0.6 & 0.6 & 0.3 \\
\hline 6 & 0.6 & 0.7 & 0.8 & 0.9 & 0.1 \\
\hline 11 & 0.3 & 0.3 & 0.4 & 0.3 & \\
\hline \multicolumn{7}{|c|}{ Bands observed using spray reagents } \\
\hline 7 & 1.8 & 3.7 & 3.3 & 3.4 & 3.8 \\
\hline 8 & 1.4 & 2.7 & 2.9 & 3.0 & 2.8 \\
\hline 9 & 0.6 & 1.9 & 2.0 & 1.9 & 0.4 \\
\hline 10 & 0.8 & 1.0 & 0.7 & 0.9 & - \\
\hline Ethanol & - & - & - & - & 3.4 \\
\hline Ketoconazole & 3.9 & 3.8 & 3.6 & 3.5 & \\
\hline
\end{tabular}

Ethanol - Negative control; Ketoconazole - Positive control

Table 3: Miniumum inhibitory concentration for band 7 of $P$. minus against plant pathogens by tube dilution method

\begin{tabular}{|c|c|c|c|c|}
\hline \multirow{2}{*}{ Organism } & \multicolumn{4}{|c|}{ Chloroform extract of P. minus } \\
\cline { 2 - 5 } & Dilution 1 (10mg) & Dilution 2 (1mg) & Dilution 3 (0.1mg) & Dilution 4 (0.01mg) \\
\hline A. solani & NG & NG & G & G \\
\hline A. flavus & NG & NG & G & G \\
\hline A. niger & NG & NG & G & G \\
\hline F. oxysporum f.sp. lycopersici & NG & NG & G & G \\
\hline Ethanol & G & G & G & G \\
\hline Ketoconazole & NG & NG & G & G \\
\hline Cells & G & G & G & G \\
\hline
\end{tabular}

NG - No growth; G - Growth Ethanol - Negative control; Ketoconazole - Positive control

Table 4a: Miniumum inhibitory concentration for band 7 of $P$. minus using ELISA reader against $A$. solani

\begin{tabular}{|c|c|c|c|c|c|c|}
\hline Concentration (mg/ml) & *Broth + band & Cells + band & Ethanol & Ketaconazole & $*$ Broth & Cells \\
\hline \multicolumn{7}{|c|}{ Observation at 0 } \\
\hline \multicolumn{7}{|c|}{ hour } \\
\hline 10.0 & 1.694 & 1.793 & 0.099 & 0.101 & \multirow{2}{*}{0.061} & \multirow{2}{*}{0.096} \\
\hline
\end{tabular}




\begin{tabular}{|c|c|c|c|c|c|c|}
\hline 0.1 & 0.124 & 0.165 & 0.096 & 0.098 & & \\
\hline 0.01 & 0.097 & 0.117 & 0.094 & 0.096 & & \\
\hline \multicolumn{7}{|c|}{ Observation at $1^{\text {rst }}$ hour } \\
\hline 10.0 & 1.694 & 1.793 & 0.106 & 0.101 & \multirow{4}{*}{0.061} & \multirow{4}{*}{0.139} \\
\hline 1.0 & 0.559 & 0.592 & 0.110 & 0.099 & & \\
\hline 0.1 & 0.125 & 0.172 & 0.125 & 0.098 & & \\
\hline 0.01 & 0.098 & 0.128 & 0.139 & 0.121 & & \\
\hline \multicolumn{7}{|c|}{ Observation at $6^{\text {th }}$ hour } \\
\hline 10.0 & 1.694 & 1.793 & 0.149 & 0.101 & \multirow{4}{*}{0.062} & \multirow{4}{*}{0.179} \\
\hline 1.0 & 0.559 & 0.592 & 0.156 & 0.099 & & \\
\hline 0.1 & 0.125 & 0.189 & 0.163 & 0.098 & & \\
\hline 0.01 & 0.099 & 0.199 & 0.172 & 0.143 & & \\
\hline \multicolumn{7}{|c|}{ Observation at $\mathbf{2 4}^{\text {th }}$ hour } \\
\hline 10.0 & 1.694 & 1.794 & 0.210 & 0.101 & \multirow{4}{*}{0.063} & \multirow{4}{*}{0.272} \\
\hline 1.0 & 0.560 & 0.592 & 0.234 & 0.099 & & \\
\hline 0.1 & 0.125 & 0.209 & 0.258 & 0.098 & & \\
\hline 0.01 & 0.099 & 0.270 & 0.269 & 0.202 & & \\
\hline
\end{tabular}

Ethanol - Negative control; Ketoconazole - Positive control

* Potato Carrot broth Absorbance at $620 \mathrm{~nm}$

Table 4b: Minimum inhibitory concentration for band 7 of $P$. minus using ELISA reader against $F$. oxysporum f.sp. lycopersici

\begin{tabular}{|c|c|c|c|c|c|c|}
\hline Concentration (mg/ml) & *Broth + band & Cells + band & Ethanol & Ketaconazole & *Broth & Cells \\
\hline \multicolumn{7}{|c|}{ Observation at $0^{\text {th }}$ hour } \\
\hline 10.0 & 1.676 & 1.713 & 0.091 & 0.096 & \multirow{4}{*}{0.059} & \multirow{4}{*}{0.086} \\
\hline 1.0 & 0.532 & 0.531 & 0.089 & 0.092 & & \\
\hline 0.1 & 0.112 & 0.139 & 0.087 & 0.090 & & \\
\hline 0.01 & 0.089 & 0.089 & 0.084 & 0.089 & & \\
\hline \multicolumn{7}{|c|}{ Observation at $1^{\text {rst }}$ hour } \\
\hline 10.0 & 1.676 & 1.713 & 0.098 & 0.096 & \multirow{4}{*}{0.059} & \multirow{4}{*}{0.112} \\
\hline 1.0 & 0.532 & 0.531 & 0.099 & 0.092 & & \\
\hline 0.1 & 0.113 & 0.142 & 0.109 & 0.090 & & \\
\hline 0.01 & 0.090 & 0.108 & 0.111 & 0.099 & & \\
\hline \multicolumn{7}{|c|}{ Observation at $6^{\text {th }}$ hour } \\
\hline 10.0 & 1.676 & 1.713 & 0.118 & 0.096 & \multirow{4}{*}{0.058} & \multirow{4}{*}{0.134} \\
\hline 1.0 & 0.532 & 0.531 & 0.122 & 0.092 & & \\
\hline 0.1 & 0.113 & 0.145 & 0.129 & 0.095 & & \\
\hline 0.01 & 0.090 & 0.129 & 0.135 & 0.119 & & \\
\hline \multicolumn{7}{|c|}{ Observation at $24^{\text {th }}$ hour } \\
\hline 10.0 & 1.676 & 1.713 & 0.166 & 0.096 & \multirow{4}{*}{0.057} & \multirow{4}{*}{0.189} \\
\hline 1.0 & 0.533 & 0.532 & 0.172 & 0.092 & & \\
\hline 0.1 & 0.114 & 0.168 & 0.180 & 0.090 & & \\
\hline 0.01 & 0.091 & 0.187 & 0.190 & 0.162 & & \\
\hline
\end{tabular}

Thanol - Negative control; Ketoconazole - Positive control

*Armstrong Fusarium broth Absorbance at $620 \mathrm{~nm}$

Table 4c: Miniumum inhibitory concentration for band 7 of $P$. minus using ELISA reader against $A$. flavus

\begin{tabular}{|c|c|c|c|c|c|c|}
\hline Concentration (mg/ml) & *Broth + band & Cells + band & Ethanol & Ketaconazole & *Broth & Cells \\
\hline \multicolumn{7}{|c|}{ Observation at $0^{\text {th }}$ hour } \\
\hline 10.0 & 1.698 & 1.802 & 0.103 & 0.112 & \multirow{4}{*}{0.063} & \multirow{4}{*}{0.099} \\
\hline 1.0 & 0.563 & 0.600 & 0.101 & 0.108 & & \\
\hline 0.1 & 0.132 & 0.181 & 0.099 & 0.105 & & \\
\hline 0.01 & 0.098 & 0.123 & 0.098 & 0.102 & & \\
\hline \multicolumn{7}{|c|}{ Observation at $1^{\text {rst }}$ hour } \\
\hline 10.0 & 1.698 & 1.802 & 0.121 & 0.112 & \multirow{4}{*}{0.063} & \multirow{4}{*}{0.151} \\
\hline 1.0 & 0.563 & 0.600 & 0.135 & 0.108 & & \\
\hline 0.1 & 0.133 & 0.191 & 0.146 & 0.105 & & \\
\hline 0.01 & 0.098 & 0.144 & 0.150 & 0.120 & & \\
\hline \multicolumn{7}{|c|}{ Observation at $6^{\text {th }}$ hour } \\
\hline 10.0 & 1.698 & 1.802 & 0.175 & 0.112 & \multirow{4}{*}{0.064} & \multirow{4}{*}{0.189} \\
\hline 1.0 & 0.564 & 0.600 & 0.179 & 0.108 & & \\
\hline 0.1 & 0.134 & 0.198 & 0.183 & 0.105 & & \\
\hline 0.01 & 0.100 & 0.182 & 0.186 & 0.146 & & \\
\hline \multicolumn{7}{|c|}{ Observation at $24^{\text {th }}$ hour } \\
\hline 10.0 & 1.699 & 1.802 & 0.229 & 0.112 & \multirow{4}{*}{0.065} & \multirow{4}{*}{0.297} \\
\hline 1.0 & 0.565 & 0.600 & 0.241 & 0.108 & & \\
\hline 0.1 & 0.135 & 0.221 & 0.278 & 0.109 & & \\
\hline 0.01 & 0.100 & 0.295 & 0.298 & 0.197 & & \\
\hline
\end{tabular}

Ethanol - Negative control; Ketoconazole - Positive control 
*Aspergillus Differential broth Absorbance at 620nm

Table 4d: Minimum inhibitory concentration for band 7 of $P$. minus using ELISA reader against $A$. niger

\begin{tabular}{|c|c|c|c|c|c|c|}
\hline Concentration (mg/ml) & *Broth + band & Cells + band & Ethanol & Ketaconazole & *Broth & Cells \\
\hline \multicolumn{7}{|c|}{ Observation at $0^{\text {th }}$ hour } \\
\hline 10.0 & 1.691 & 1.788 & 0.096 & 0.107 & \multirow{4}{*}{0.061} & \multirow{4}{*}{0.096} \\
\hline 1.0 & 0.559 & 0.579 & 0.094 & 0.105 & & \\
\hline 0.1 & 0.142 & 0.168 & 0.093 & 0.103 & & \\
\hline 0.01 & 0.099 & 0.117 & 0.091 & 0.099 & & \\
\hline \multicolumn{7}{|c|}{ Observation at $1^{\text {rst }}$ hour } \\
\hline 10.0 & 1.691 & 1.788 & 0.119 & 0.107 & \multirow{4}{*}{0.061} & \multirow{4}{*}{0.147} \\
\hline 1.0 & 0.559 & 0.579 & 0.129 & 0.105 & & \\
\hline 0.1 & 0.144 & 0.172 & 0.137 & 0.103 & & \\
\hline 0.01 & 0.101 & 0.136 & 0.141 & 0.117 & & \\
\hline \multicolumn{7}{|c|}{ Observation at $6^{\text {th }}$ hour } \\
\hline 10.0 & 1.691 & 1.788 & 0.138 & 0.107 & \multirow{4}{*}{0.061} & \multirow{4}{*}{0.179} \\
\hline 1.0 & 0.559 & 0.579 & 0.146 & 0.105 & & \\
\hline 0.1 & 0.145 & 0.184 & 0.164 & 0.103 & & \\
\hline 0.01 & 0.101 & 0.169 & 0.176 & 0.136 & & \\
\hline \multicolumn{7}{|c|}{ Observation at $24^{\text {th }}$ hour } \\
\hline 10.0 & 1.692 & 1.790 & 0.219 & 0.107 & \multirow{4}{*}{0.062} & \multirow{4}{*}{0.288} \\
\hline 1.0 & 0.561 & 0.580 & 0.239 & 0.105 & & \\
\hline 0.1 & 0.146 & 0.212 & 0.278 & 0.103 & & \\
\hline 0.01 & 0.101 & 0.276 & 0.287 & 0.193 & & \\
\hline
\end{tabular}

Ethanol - Negative control; Ketoconazole - Positive control

*Czapek yeast extract broth

Absorbance at 620nm

Table 5: MIC result of band 7 of $P$. minus against plant pathogens at $1 \mathrm{mg}$ concentration in ELISA reader

\begin{tabular}{|c|c|c|c|c|c|c|}
\hline \multirow{2}{*}{ Organism } & \multicolumn{4}{|c|}{ Contents } & \multirow{2}{*}{ SEd } & \multirow{2}{*}{ CD (0.05) } \\
\hline & Band $7+$ cells $(1 \mathrm{mg} / \mathrm{ml})$ & Ethanol & Ketoconazole & Cells & & \\
\hline A.solani $0^{\text {th }}$ hour & 0.592 & 0.098 & \begin{tabular}{|l|l}
0.099 \\
\end{tabular} & 0.096 & 0.0226 & 0.0522 \\
\hline $1^{\text {rst }}$ hour & 0.592 & 0.110 & 0.099 & 0.139 & 0.0230 & 0.0530 \\
\hline $6^{\text {th }}$ hour & 0.592 & 0.156 & 0.099 & 0.179 & 0.1279 & 0.2949 \\
\hline $24^{\text {th }}$ hour & 0.592 & 0.234 & 0.099 & 0.272 & 0.0257 & 0.0593 \\
\hline A.flavus $0^{\text {th }}$ hour & 0.600 & 0.101 & 0.108 & 0.099 & 0.0230 & 0.0530 \\
\hline $1^{\text {rst }}$ hour & 0.600 & 0.135 & 0.108 & 0.151 & 0.0236 & 0.0544 \\
\hline $6^{\text {th }}$ hour & 0.600 & 0.179 & 0.108 & 0.189 & 0.0244 & 0.0562 \\
\hline $24^{\text {th }}$ hour & 0.600 & 0.241 & 0.108 & 0.297 & 0.0264 & 0.0610 \\
\hline A.niger $0^{\text {th }}$ hour & 0.579 & 0.094 & 0.105 & 0.096 & 0.0222 & 0.0222 \\
\hline $1^{\text {rst }}$ hour & 0.579 & 0.129 & 0.105 & 0.147 & 0.0228 & 0.0525 \\
\hline $6^{\text {th }}$ hour & 0.579 & 0.146 & 0.105 & 0.179 & 0.0232 & 0.0536 \\
\hline $24^{\text {th }}$ hour & 0.580 & 0.239 & 0.105 & 0.288 & 0.0257 & 0.0592 \\
\hline F.oxysporum f.sp. lycopersici $0^{\text {th }}$ hour & 0.531 & 0.089 & 0.092 & 0.086 & 0.0203 & 0.0468 \\
\hline $1^{\text {rst }}$ hour & 0.531 & 0.099 & 0.092 & 0.112 & 0.0205 & 0.0474 \\
\hline $6^{\text {th }}$ hour & 0.531 & 0.122 & 0.092 & 0.134 & 0.0209 & 0.0482 \\
\hline $24^{\text {th }}$ hour & 0.531 & 0.172 & 0.092 & 0.189 & 0.0219 & 0.0505 \\
\hline
\end{tabular}

Ethanol - Negative control; Ketoconazole - Positive control Absorbance at 620nm

Table 6: Miniumum inhibitory concentration for band 8 of $P$. minus against human pathogens by tube dilution method

\begin{tabular}{|c|c|c|c|c|}
\hline \multirow{2}{*}{ Organism } & \multicolumn{4}{|c|}{ Chloroform leaf extract of $P$. minus } \\
\hline & Dilution 1 (10mg) & Dilution 2 (1mg) & Dilution $3(0.1 \mathrm{mg})$ & Dilution 4 (0.01mg) \\
\hline \multicolumn{5}{|c|}{ Gram positive bacteria } \\
\hline S. aureus & NG & NG & $\mathrm{G}$ & $\mathrm{G}$ \\
\hline \multicolumn{5}{|c|}{ Gram negative bacteria } \\
\hline E. coli & NG & NG & G & G \\
\hline P. aeruginosa & NG & NG & G & G \\
\hline \multicolumn{5}{|c|}{ Fungi } \\
\hline C. albicans & NG & NG & $\mathrm{G}$ & $\mathrm{G}$ \\
\hline C. neoformans & NG & NG & $\mathrm{G}$ & $\mathrm{G}$ \\
\hline Ethanol & $\mathrm{G}$ & $\mathrm{G}$ & $\mathrm{G}$ & $\mathrm{G}$ \\
\hline Chloramphenicol & NG & NG & $\mathrm{G}$ & $\mathrm{G}$ \\
\hline Cells & $\mathrm{G}$ & $\mathrm{G}$ & $\mathrm{G}$ & $\mathrm{G}$ \\
\hline
\end{tabular}

NG - No growth; G - Growth

Ethanol - Negative control; Chloramphenicol - Positive control 
Table 7: Inhibitory concentration 50 for band 7 of $P$. minus against plant pathogens

\begin{tabular}{|c|c|c|c|c|c|c|}
\hline \multirow{2}{*}{ Organism } & \multicolumn{7}{c|}{ Band concentration (mg/ml) } & \multirow{2}{*}{ Ketoconazole } & \multirow{2}{*}{ Cells } \\
\cline { 2 - 5 } & $\mathbf{1 . 0 0}$ & $\mathbf{0 . 7 5}$ & $\mathbf{0 . 5 0}$ & $\mathbf{0 . 2 5}$ & & \\
\hline \multicolumn{7}{|c|}{ A.solani } \\
\hline No. of colonies x 10
\end{tabular}

Ketoconazole - Positive control

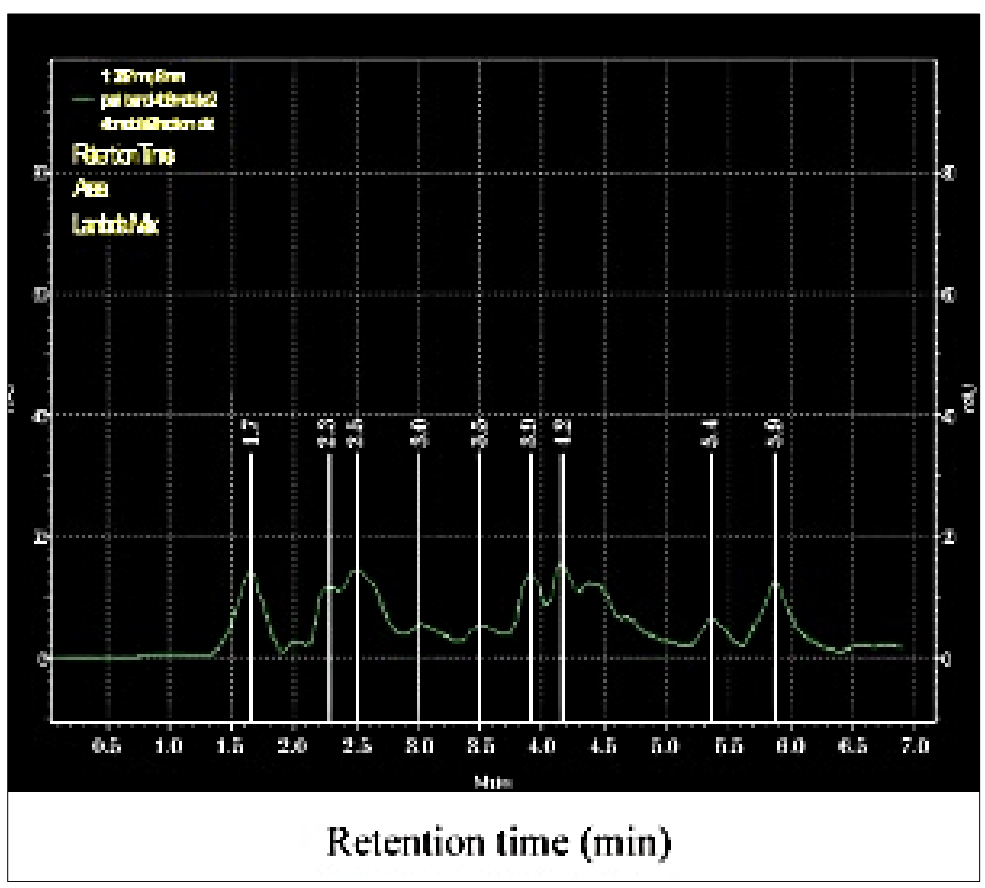

Fig 1: HPLC fractionation of band 7 of chloroform extract of P. minus

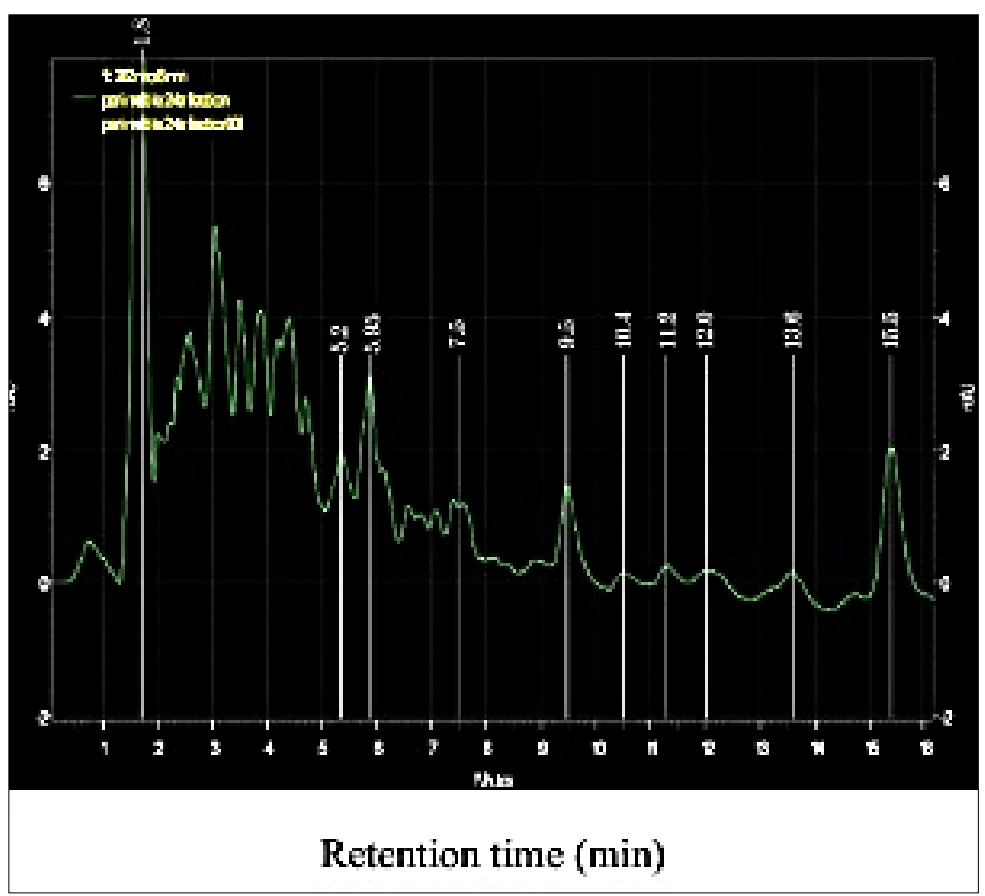

Fig 2: HPLC fractionation of band 8 of chloroform extract of P. minus 


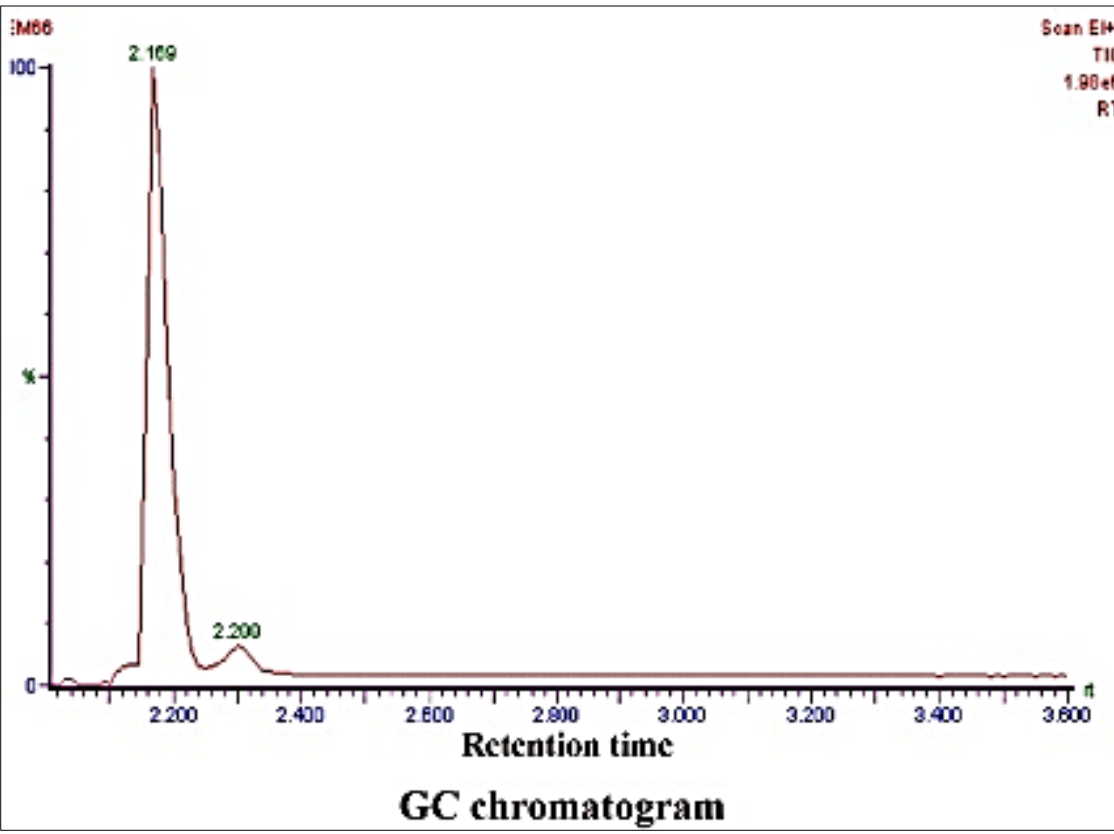

\section{EN/39 132(2)}

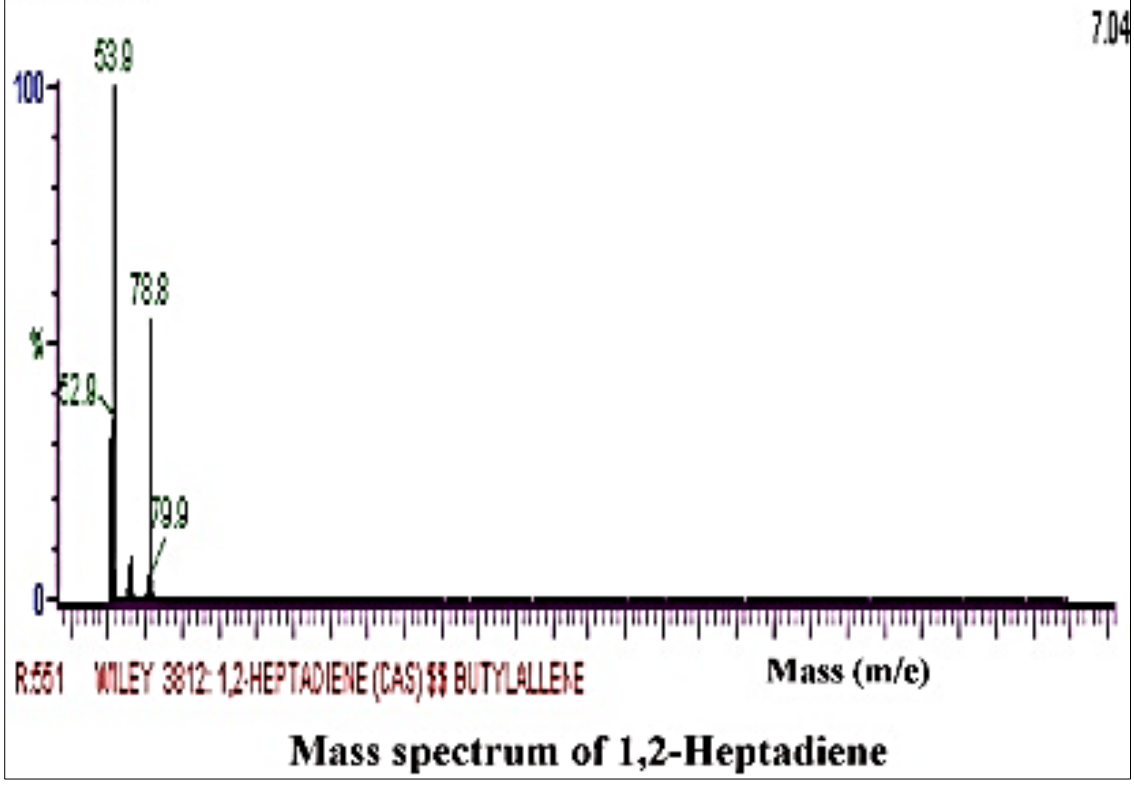

Fig 3: GC-MS Analysis of HPLC fraction 2 of band 7 obtained from chloroform extract of Polygonum minus

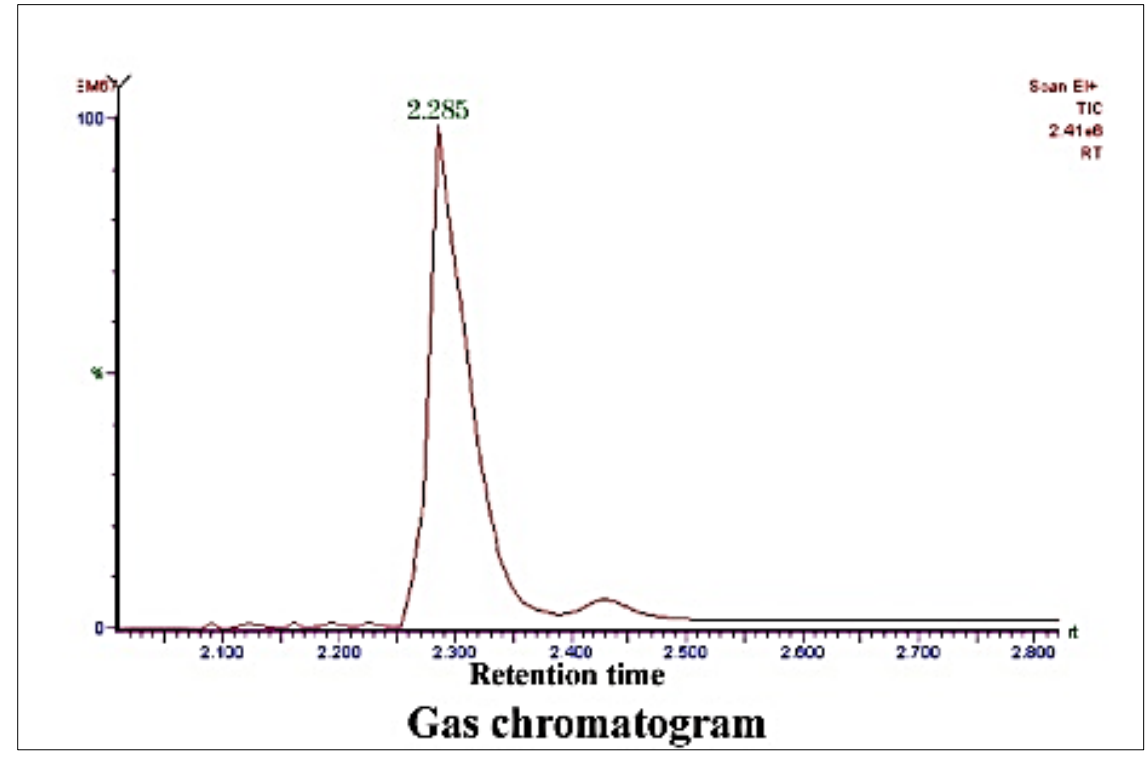




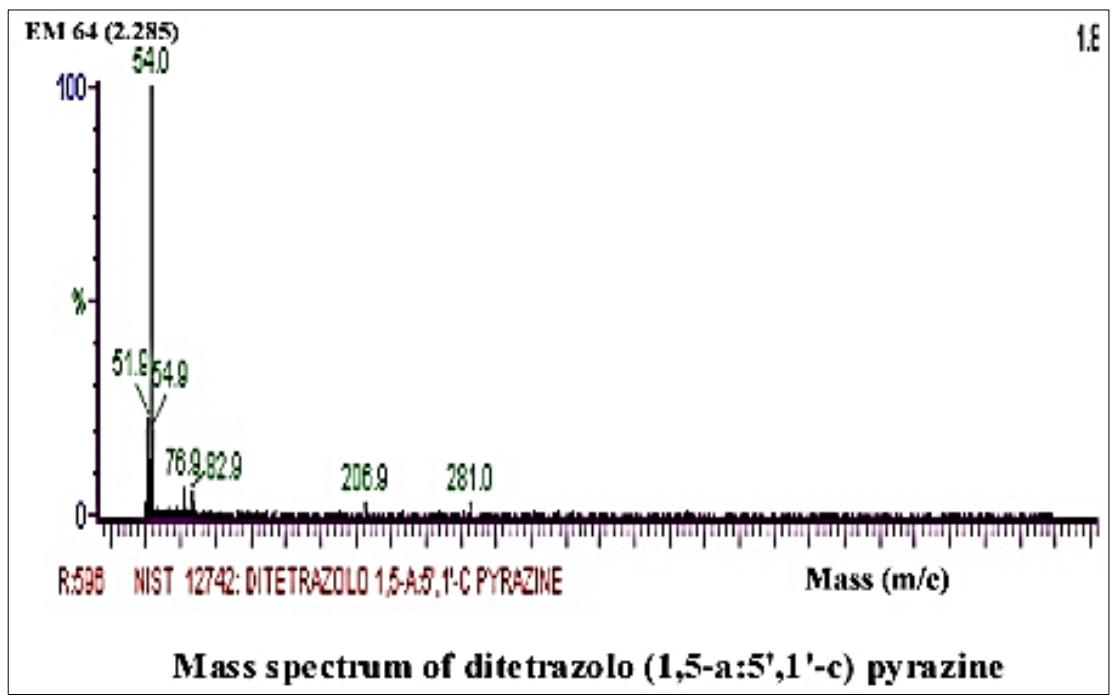

Fig 4: GC-MS Analysis of HPLC fraction 8 of band 7 of chloroform extract of Polygonum minus

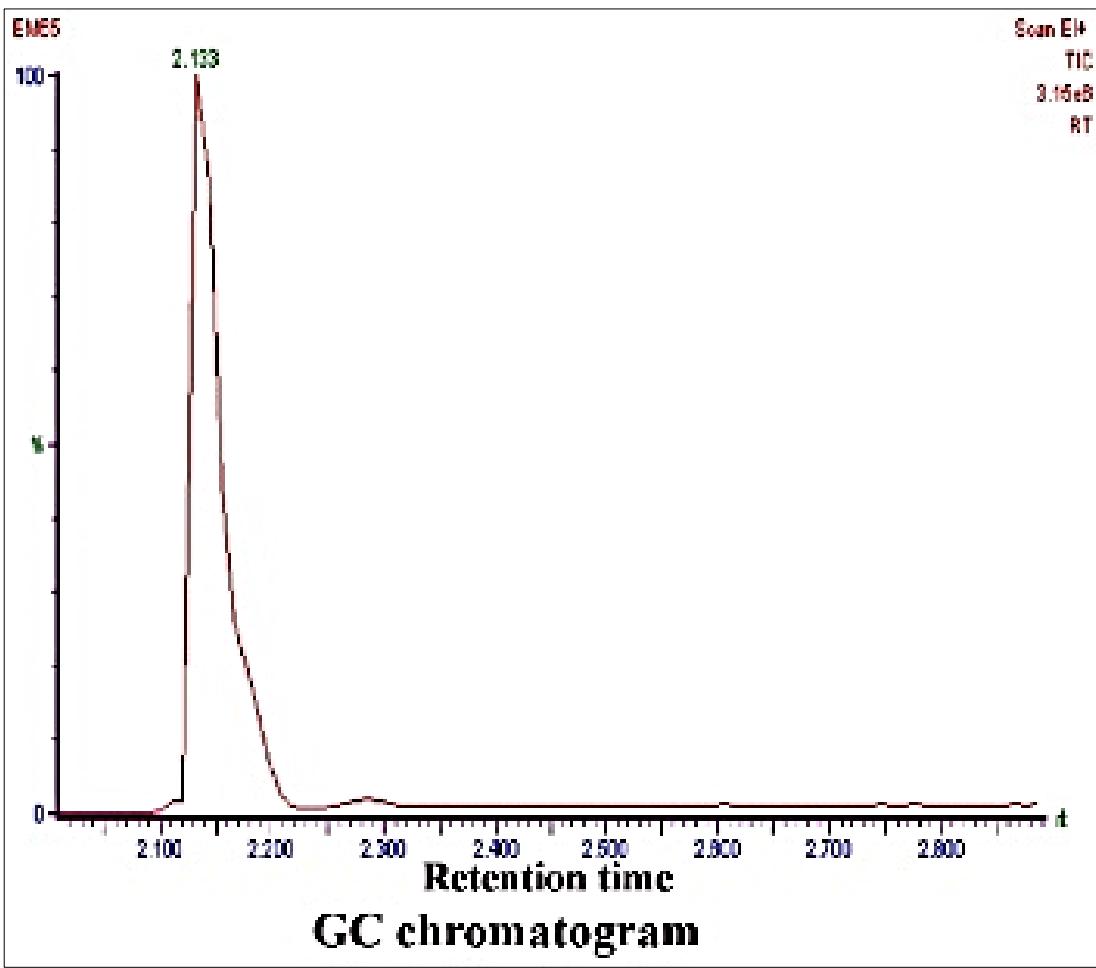

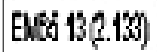

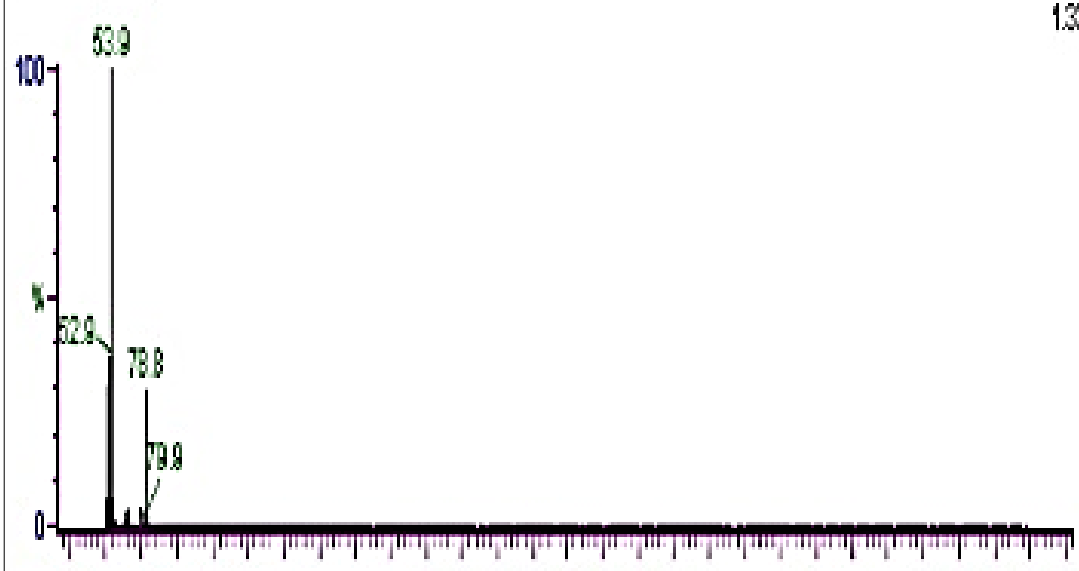

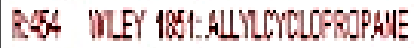

Mass (m/e)

Mass spectrum of allylcyclopropane obtained from IIPLC fraction 2 of hand 8

Fig 5: GC-MS Analysis of HPLC fraction 2 of band 8 of chloroform extract of Polygonum minus $\sim 3487 \sim$ 


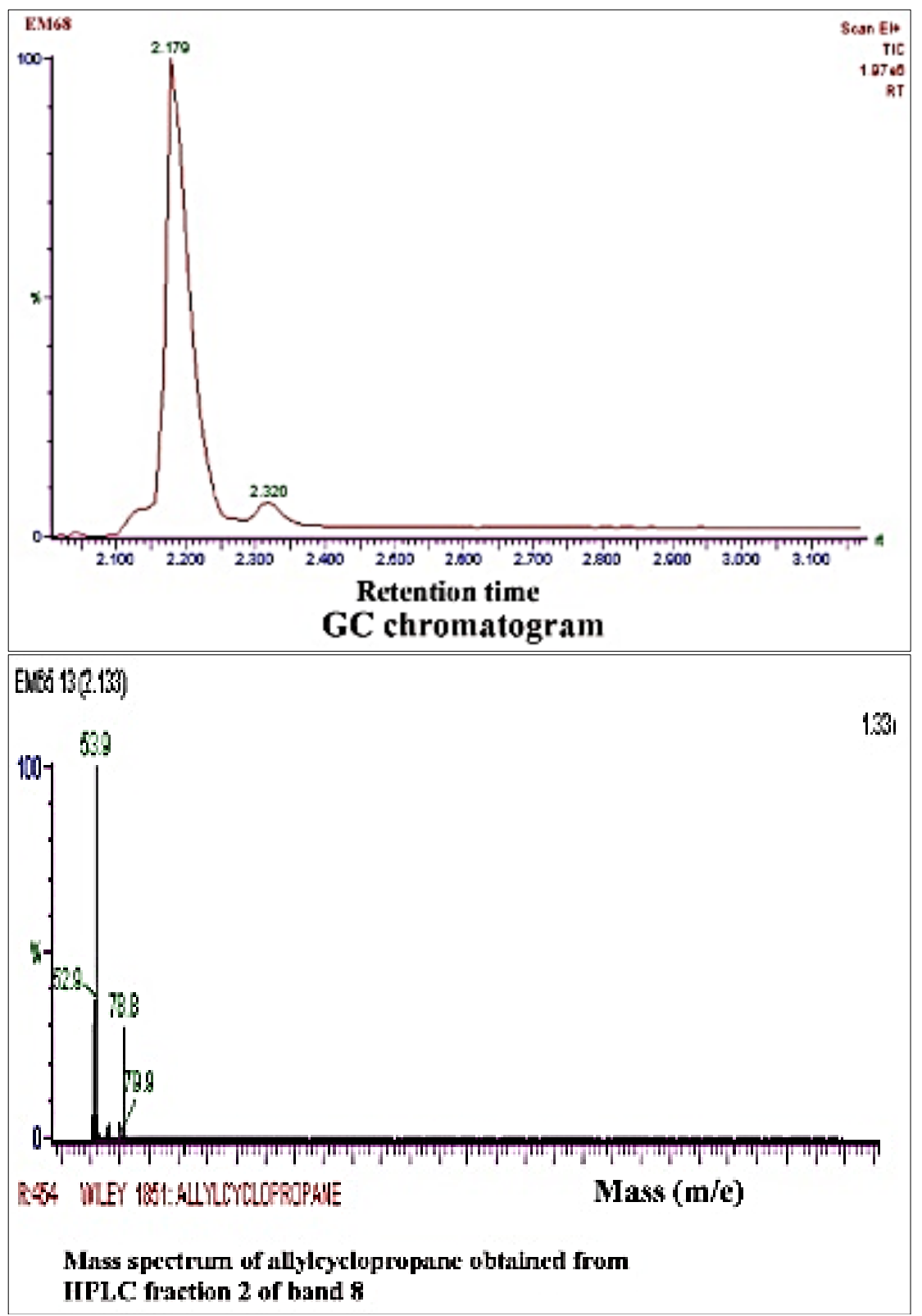

Fig 6: GCMS Analysis of HPLC fraction 9 of band 8 of chloroform extract of Polygonum minus

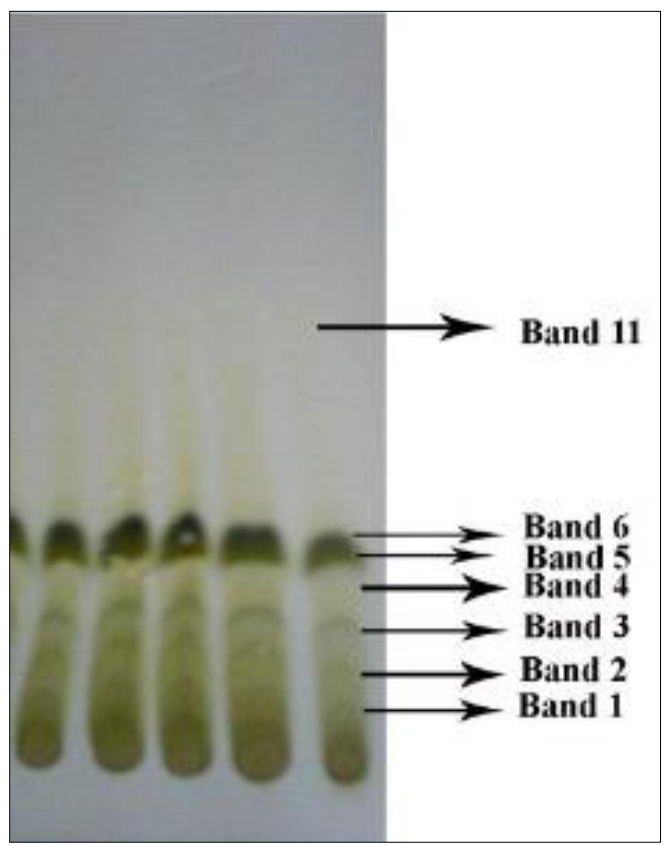

Plate 1: Thin layer chromatography for chloroform extract of $P$. minus - Visible observation 


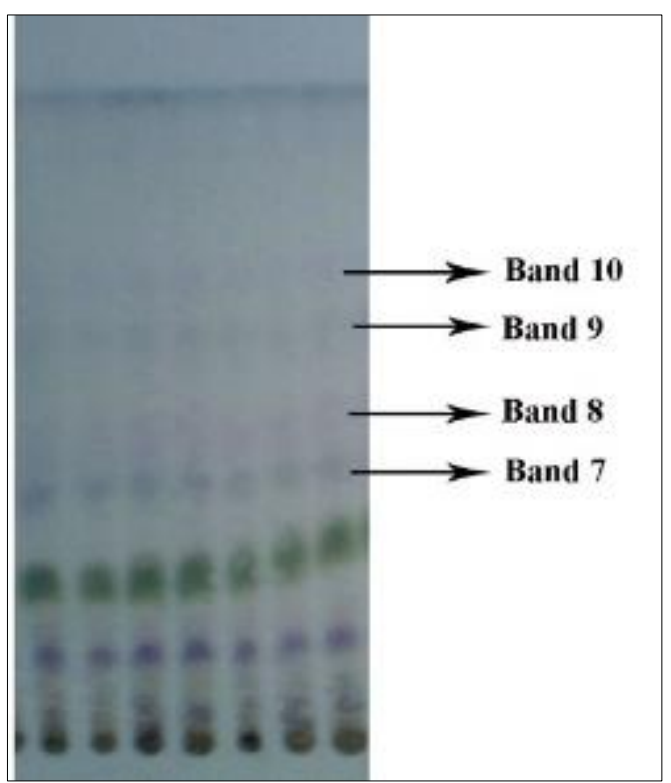

Plate 2: Thin layer chromatography for chloroform extract of P. Minus - Bands observed using vanillin sulphuric acid

\section{References}

1. Apers S, Pieters $\mathrm{L}$, Miert S, Hermans AJ. In vitro antimicrobial activity of fresh apical stem of Phyllanthus niruri. J. Ehnopharmacol. 2004; 95:399-404.

2. Abere TA, Onyekweli AO, Ukoh GU. In vitro antimicrobial activity of the extract of Mitracarpus scaber leaves formulated as syrup. Trop. J. Pharm. Res. 2007; 6(1):679-682.

3. Adelina JM, Rrameriza MR, Javier T. Activity against multi-drug resistant Mycobacterium tuberculosis in mexican plants used to treat respiratory diseases. Pharmacology. 2002; 17:903-908.

4. Ahn ES, Kim YS, Shin DH. Observation of bactericidal effect of allyl isothiocyanate on Listeria monocytogenes. Food Sci. Biotechnol. 2001; 10:31-35.

5. Bonjar GH. Inhibition of Clotrimazole-resistant Candida albicans by plants used in Iranian folkloric medicine. Fitoterapia. 2004; 75(1):74-76.

6. Bonjar GHS, Nik AK, Heydari MR, Ghasemzadeh MH, Farrokhi PR, Moein MR et al. Anti-Pseudomona and Anti-Bacilli activity of some medicinal plants of Iran. DARU. 2003; 11(4):157-163.

7. Claeys M, Pieters L, Corthout J, Vanden Berghe DA, Vlietinck AJ. A new antimicrobially active flavonoid from Lantanna trifolia. J. Nat. Prod. 1988; 51(5):966968.

8. Datta BK, Datta SK, Rashid MA, Nash RJ, Sarker SD. A sesquiterpene acid and flavonoids from Polygonum viscosum. Phytochem. 2000; 54:201-205.

9. Duwiejua M, Zeitlin I, Gray A, Waterman P. The antiinflammatory compounds of Polygonum bistorta: isolation and characterization. Planta Med. 1999; 65:371374.

10. Fernand G, Accrombessi M, Joelle A. HPLC quantification at two isomeric triterpenic acids isolated from Mitracarpus scaber and antimicrobial activity - on Termatophilus congolensis. J. Pharm. Biomed. Anal. 2005; 39:990-995.

11. Govindachari TR, Suresh G, Geetha G, Balagangan B, Masilamani S. Identification of antifungal compounds from seed oil of Azadirachta indica. Phytoparasitica. $1998 ; 26: 1-8$.
12. Hahn DD, Faubion JM, Rooney LW. Sorghum phenolic acids their high performance liquid chromatographic separation and their relation to fungal resistance. Cereal Chem. 1993; 60(4):255.

13. Huang KC. The Pharmacology of Chinese Herbs. CRC Press, Boca Raton, FL. USA, 1993, 101-296.

14. Iqbal A, Zafar M, Faiz M. Screening of some medicinal plants for their antimicrobial activities. J. Ehnopharmacol. 1998; 62:183-193.

15. Jayasuriya H, Koonchanok NM, Geahlen RL, McLaughli JL, Chang CJ. Emodin, a protein tyrosine kinase inhibitor from Polygonum cupsidatum. J. Nat. Prod. 1992; 55:696698.

16. Jiang J. Volatile composition of the laksa plant (Polygonum hydropiper L.), a potential source of green note aroma compounds. Flavour Fragr. J. 2005; 20: 455459.

17. Kim H, Woo E, Park H. A novel lignan and flavonoids from Polygonum aviculare. J. Nat. Prod. 1994; 57:581586.

18. Kimura Y, Kozawa M, Baba K, Hata K. New constituents of the roots of Polygonum cuspidatum. Planta Med. 1983; 48(3):164-168.

19. Krivopalov VP, Baram SG, Yu A, Denisov, Mamatyuk VI. Azide-tetrazole tautomerism of diazidodiazines and their benzo analogs. Russ. Chem. Bull. 1989; 38(9):18391844.

20. Ling CAI, Ai-Yang LI. Extraction and GC/MS analysis of volatile oil from Polygonum orientale L. Journal of Chinese Mass Spectrometry. 2008; 29(3):157-161.

21. Manmoud S, Vanden Berghe DA, Vlietinck AJ. A new antimicrobially active flavonoid from Lantana camara. J. Nat. Prod. 1999; 51(5):966-968.

22. Matsuda H, Shimoda H, Morikawa T, Yoshikawa M. Phytoestrogens from the roots of Polygonum cupsisdatum (Polygonaceae): structure-requirement of hydroxyanthraquinones for estrogenic activity. Bioorg. Med. Chem. Lett. 2001; 11:1839-1842.

23. Murai Y, Kashimura S, Tamezawa S, Hashimoto T, Asakawa S, Kiguchi K et al. Absolute configuration of (6S,9S)-roseoside from Polygonum hydropiper. Planta Med. 2001; 67:480-481. 
24. Nonaka G, Miwa N, Nishioka I. Stilbene glycoside gallates and proanthocyanidins from Polygonum multiflorum. Phytochem. 1982; 21:429-432.

25. Park JH, Lee JK. The Encyclopedia of Medicinal Plants. Shinil Books Co. Ltd, Seoul, Korea, 2000.

26. Peng ZF, Strack D, Baumert A, Subramaniam R, Goh NK, Chia TF et al. Antioxidant flavonoids from leaves of Polygonum hydropiper L. Phytochem. 2003; 62:219-228.

27. Phongpaichit S, Pujenjob N, Ruka Chaisirikul V, Engsakul M. Antifungal activity from leaf extracts of Cassia alata L., Cassia fistula L. and Cassia tora L. J. Sci. Technol. 2004; 26(5):741-748.

28. Rao MR, Reddy IB, Ramana. Antimicrobial activity of some Indian medicinal plants. Indian J. Microbiol. 2006; 46(3):259-262.

29. Sadasivam S, Manikam M. Biochemical methods. New Age International (p) Limited, Publishers, New Delhi, 2005, 256p.

30. Shan B, Cai YZ, Brooks JD, Corke H. Antibacterial properties of Polygonum cuspidatum roots and their major bioactive constituents. Food chem. 2008; 109:530537.

31. Sartor CFP, da Silva CC, de Souza MC. Flavonoids glycosides of Polygonum stelligerum Cham. Biochem. Sys. Ecol. 1999; 27:303-304.

32. Sun X, Sneden A. Neoflavonoids from Polygonum perfoliatum. Planta Med. 1999; 65:671-673.

33. Takasaki M, Konoshima T, Kuroki S, Tokuda H, Nishino $\mathrm{H}$. Cancer chemopreventive activity of phenylpropanoid esters of sucrose, vanicoside B and lapathoside A from Polygonum lapathifolium. Cancer Lett. 2001; 173:133138.

34. Tsao SM, Yin MC. In vitro antimicrobial activity of four diallyl sulphides occurring naturally in garlic and Chinese leek oils. J. Med. Microbiol. 2001; 50(7):646-649.

35. United States Patent, No. 3988455. Ditetrazolo (1,5a:5',1'-c) quinoxalines for control of soil-borne phytopathogens.

36. United States Patent, No. 4008322. Triazolo (4,3-a) quinoxalines for control of rice blast.

37. United States Patent, No.3987196. Tetrazolo (1,5-a) quinoxalines for control of phytopathogens.

38. Vastano BC, Chen Y, Zhu N, Ho CT, Zhou Z, Rosen RT. Isolation and identification of stilbenes in two varieties of Polygonum cupsidatum. J. Agric. Food Chem. 2000; 48:253-256.

39. Voravuthikunchai S, Lortheeranuwat A, Jeeju W, Sririrak T, Phongpaichit S, Supawita T. Effective medicinal plants against enterohaemorrhagic Escherichia coli O157:H7. J. Ethnopharmacol. 2004; 94(1):49-54.

40. Wagavi SAH, Khan MSY, Vohra SB. Anti-bacterial and anti-fungal investigations of Indian medicinal plants. Fitotorepia, 1999; 62:221-228.

41. Wang K, Zhang Y, Yang CH. Antioxidant phenolic compounds from rhizomes of Polygonum paleaceum. J. Ethnopharmacol. 2005; 96:483-487.

42. Yim T, Wu W, Mak D, Ko K. Myocardial protective effect of an anthraquinone containing extract of Polygonum multiflorum exvivo. Planta Med. 1998; 64:607-611. 